\title{
Peran Guru Dalam Membentuk Karakter Siswa Peduli Terhadap Lingkungan Pada Sekolah Adiwiyata di SD
}

\section{Dinda Salsa Meika R ${ }^{1 *}$, Elpri Darta Putra ${ }^{2}$}

\author{
1,2 PGSD, Universitas Islam Riau , Pekanbaru, Indonesia
}

\section{ART ICLE IN F O}

Article history:

Received September 22, 2021

Revised September 25, 2021

Accepted October 30, 2021

Available online December 25, 2021

Kata Kunci:

Adiwiyata, Sikpa Peduli

Lingkungan, Peran Guru

Keywords:

Character,School

Environment,Teacher Role

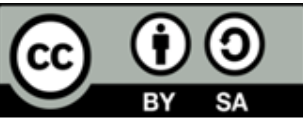

This is an open access article under the CC BY-SA license.

Copyright $(2021$ by Author. Published by Universitas Pendidikan Ganesha.

\begin{abstract}
A B S T R A K
Salah satu sekolah yang menerapkan program sekolah Adiwiyata, dan menemukan permasalahan seperti tidak adannya sanksi atau hukuman terhdap warga sekolah atau peserta didik yang melanggar peratura. Masih banyak ditemui siswa/i yang membuang sampah tidak pada tempatnya,dan adanya kegiatan. Penelitian ini bertujuan untuk menganalisis pelaksanaan program Adiwiyata dalam membentuk karakter siswa dan kendala yang dialami guru untuk membentui karakter siswa. Penelitian ini menggunakan pendekatan kualitatif. Sumber data penelitian ini adalah kepala sekolah dan 2 guru kelas V. Hasil penelitian menunjukan pelaksanaan adiwiyata SD telah diterapkan dengan baik. Seperti contoh sekolah telah mempersiapkan segala sarana dan prasarana yang menunjang program adiwiyata. hal ini memberikan pemahaman kepada seluruh stake holder sekolah adiwiyata. Peran guru dalam menumbuhkan sikap peduli lingkungan juga terlihat dalam kegiatan pembelajaran dikelas maupun diluar kelas. Sebagai contoh kegiatan di dalam kelas ialah menyelipkan pembelajaran lingkungan hidup kedalam mata pelajaran walapun dari walikota sendiri tidak ada SK mengenai lingkungan hidup. Implikasi penelitian ini diharapkan guru memiliki RPP sebagai pedoman dalam mengerjakan pendidikan lingkungan hidup atau sikap peduli lingkungan kepada peserta didik.
\end{abstract}

\section{A BS TRACT}

One of the schools that implemented the Adiwiyata school program, and found problems such as the absence of sanctions or penalties for school residents or students who violate regulations. There are still many students who throw trash out of place, and there are activities. This study aims to analyze the implementation of the Adiwiyata program in shaping the character of students and the obstacles experienced by teachers to shape the character of students. This study uses a qualitative approach. The data sources of this study were the principal and 2 teachers of class $V$ and 2 students of class $V$. The results showed. The results of the study are as follows: the implementation of SD Adiwiyata has been implemented well. For example, the school has prepared all the facilities and infrastructure that support the Adiwiyata program. this provides an understanding to all Adiwiyata school stakeholders. The teacher's role in fostering an attitude of caring for the environment is also seen in learning activities in the classroom and outside the classroom. For example, activities in the classroom are inserting environmental learning into subjects even though there is no decree from the mayor himself regarding the environment. The implication of this research is that teachers are expected to have lesson plans as a guide in carrying out environmental education or environmental care attitudes to students.

\section{PENDAHULUAN}

Karakter merupakan pembawaan individu baik itu dari sifat, watak, kepribadian, maupun tingkah laku yang diekspresikan dalam kehidupan sehari-hari (Madja, 2019; Salsabilah et al., 2021). Karakter seseorang bisa dibawa sejak ia lahir, ataupun bisa muncul berdasarkan pengalaman pribadi seseorang. Pada dasarnya karakter seseorang bisa berubah sesuai dengan pengaruh lingkungan sekitarnya, namun kebanyakan seseorang mampu berubah ke hal yang lebih baik dan positif. Karakter 
kepribadian satu orang dengan orang lainnya berbeda-beda sesuai dengan didikannya masing-masing di rumah. Adapun karakter seseorang dapat dibagi menjadi empat, diantaranya yaitu: Plegmatis, merupakan karakter seseorang yang cinta damai, dimana seseorang yang memiliki kepribadian ini adalah seseorang yang mudah diatur, cenderung diam dan kalem, suka mengalah, dan juga memiliki rasa toleransi yang cukup tinggi, Melankolis, adalah karakter yang cenderung seseorang tersebut bersikap dengan rapi, teratur, terencana, dan mampu mempertimbangkan segala sesuatu dengan melihat hal yang kecil-kecil, Sanguinis, merupakan tipe kepribadian yang menarik, suka berbicara, suka tampil di depan umum, memiliki rasa humor yang cukup tinggi, serta memiliki rasa percaya diri yang tinggi dan Koleris, merupakan tipe kepribadian yang tegas serta seseorang yang memiliki kepribadian ini merupakan seseorang yang mampu menjadi pemimpin (Rohmah, 2018; Sunarsi \& Asmalah, 2018). Jika seseorang sudah memiliki karakter yang bagus, maka akan berpengaruh juga pada karakter terhadap lingkungan sekitarnya. Karakter peduli lingkungan merupakan tindakan seseorang dalam menjaga lingkungannya dalam kehidupan sehari-sehari, maupun upaya seseorang untuk menjaga lingkun sekitarnya serta memperbaiki segala kerusakan alam yang sudah terjadi sebelumnya (Purwanti, 2017; Tresnani, 2020). Siswa dapat dikatakan peduli terhadap lingkungannya dapat dilihat dari hal kecil yang dilakukan setiap harinya di sekolah, seperti ketika siswa meraut pencilnya apakah siswa membuang sampah rautannya sembarangan di lantai kelas, menaruhnya di kolong meja, atau membuangnya langsung ke tong sampah. Membina sikap peduli terhadap lingkungan kepada siswa dapat dilakukan dengan membiasakan siswa untuk membuang sampah pada tempatnya dan memberikan siswa jadwal piket yang telah ditentukan oleh gurunya, sehingga dengan adanya piket yang telah disepakati maka siswa akan terbiasa untuk mejaga lingkungan sekitarnya (Irwansa \& Maf'ul, 2018; Sholikhah, 2017; Syahriani et al., 2018). Oleh sebab itu, pendidikan karakter dapat terinternalisasi dan terintegrasi dalam pembelajaran di dalam maupun di luar kelas untuk membetuk perilaku peserta didik yang berkarakter.

Namun kenyataannya di lapangan pembelajaran dengan kurikulum 2013, khususnya di jenjang sekolah dasar yang diberikan penekanan lebih pada karakter siswa agar membentuk siswa yang jujur, disiplin, tanggung jawab, toleransi, gotong royong, sopan, dan percaya diri belumlah sesuai dengan apa yang diharapkan (Iswantiningtyas \& Wulansari, 2018; Putry, 2019; Wardani et al., 2019). Selain itu, hasil pendidikan mengalami kemerosotan nilai moral (Gazali et al., 2019; Rahmawati \& Harmanto, 2020). Hal ini dibuktikan dengan maraknya tawuran antar pelajar, banyaknya kelompok siswa yang ugal-ugalan motor dijalanan, dan berbagai sikap dan perilaku negatif lainnya yang ditunjukkan oleh siswa. Kerusakan lingkungan yang dibuat oleh manusia itu sendiri dapat berupa banjir, tanah longsor, dan juga pencemaran air dan udara. Banyak manusia yang kurang sadar dengan kepeduliannya terhadap lingkungan, sehingga membuat lingkungan menjadi tercemar. Nilai karakter seperti kejujuran, kesantunan, dan kebersamaan menjadi kurang diperhatikan jika bertentangan dengan tujuan yang ingin di capai. Hal dibuktikan dengan maraknya tindak kekerasan dan korupsi yang banyak muncul dalam berita nasional. Sehingga dapat dikatakan bahwa Indonesia saat ini membutuhkan tindakan yang berfokus membentuk karaktersiswa. Berdasarkan observai awal yang dilakukan di SDN 114 Pekanbaru menemukan bahwa SDN 114 Pekanbaru merupakan salah satu sekolah yang menerapkan program sekolah Adiwiyata, dan menemukan permasalahan seperti tidak adannya sanksi atau hukuman terhdap warga sekolah atau peserta didik yang melanggar peratura. Masih banyak ditemui siswa/i yang membuang sampah tidak pada tempatnya,dan adanya kegiatan. Merusak lingkungan sekolah seperti coret-coret di tembok sekolah. Kurangnya partisipasi peserta didik terhadap lingkungan. Partisipasi siswa dalam program sekolah masih dalam batas mengikuti kegiatan seminar pengelolahan lingkungan hidup dan bersih-bersih kelas. Jika permasalahan tersebut dibiarkan akan memberikan dampak terhadap kemampuan siswa.

Solusi yang dapat dilakukan yaitu dengan menumbuhkan karakter siswa melalui berbagai program lingkungan hidup (Bayu Indra Permana \& Ulfatin, 2018). Salah satu program tersebut yaitu adiwiyata. Adiwiyata adalah upaya membangun program atau wadah ideal, karna diperoleh segala jenis ilmu pengetahuan dan berbagai norma serta etika yang menjadi dasar manusia untuk kesejahteraan hidup dan menuju cita-cita pembangunan berkelanjutan (Asyifa et al., 2019; Desfandi et al., 2017). Sekolah Adiwiyata bukan hanya dilihat dari tampilan fisik sekolah yang hijau, tetapi wujud sekolah yang memiliki program dan aktivitas pendidikan yang mengarah kepada kesadaran dan kearifan warga sekolah terhadap lingkungan hidup (Nurwaqidah et al., 2020). Sekolah Adiwiyata memiliki ciri-ciri; sekolah yang nyaman dan berbudaya lingkungan, ada partisipasi dari warga sekolah untuk menciptakan sekolah Adiwiyata, melakukan pengurangan penaikan listrik, air serta menjaga kebersihan dan melakukan upaya pengelolahan lingkungan hidup, dan adannya sarana dan prasarana pendukung program adiwiyata (Bayu Indra Permana \& Ulfatin, 2018; Tompodung et al., 2018). Peraturan Mentri Negara Lingkungan Hidup Nomor 05 Tahun 2013 tentang Pedoman Pelaksanaan Adiwiyata, dan kesepakatan bersama antara Mentri Negara Lingkungan Hidup dengan Mentri Penidikan Nasional Nomor 03/ MENLH/02/2010 dan Nomor 01/11/KB/2010 tentang Program Sekolah Berbudaya Lingkungan (Adiwiyata). Sekolah Adieiyata 
merupakan sekolah yang memilikui program dan melaksankan pendidikan yang mengarah kepada kesadaran dan kearifan warga sekolah terhadap lingkungan hidup, Limawati (2018:20). Sekolah Adiwiyata memiliki ciri-ciri seperti; sekolah yang nyaman dan berbudaya lingkungan, ada patisipasi dari warga sekolah untuk menciptakan sekolah Adiwiyata melakukan penggurungan pemakaian listrik,air, dan ATK, serta menjaga kebersihan dan melakukan upaya pengelolahan lingkungan hidup, dan adannya sarana dan prasarana pendukung program Adiwiyata (Oktradiksa \& Sari, 2017; Bayu Indra Permana \& Ulfatin, 2018).

Pembentukan karakter sebaiknya dilakukan sedini mungkin agar terbentuk sumber daya manusia yang berkarakter kuat, cerdas, berbudi luhur, berhati mulia (Citra Ningrum et al., 2019; Prasanti \& Fitrianti, 2018). Beberapa temuan menyatakan dalam memberntuk karakter siswa, seorang guru harus berkarakter yang kuat dan berkepribadian yang mantap sehingga bisa menjadi teladan bagi siswanya (Pitaloka et al., 2021; Ramdan \& Fauziah, 2019). Guru tidak boleh hanya memberi contoh, tetapi harus mampu menjadi contoh atau teladan bagi siswanya. Seorang guru, terutama guru kelas memiliki peranan yang sangat menentukan dalam pembentukan kepribadian atau karakter siswa SD. Oleh karna itu, sebagai sorang guru harus berkarakter yang kuat dan berkepribadian yang mantap sehingga menjadi teladan bagi siswanya. Guru tidak boleh hanya memberi contoh, tetapi harus mampu menjadi contoh atau teladan bagi siswanya.ngka membiasakan karakter yang akan dibentuk. Melalui peran guru dalam membina karakter peduli lingkungan pada siswa, diharapkan agar siswa menjadi manusia yang bertanggung jawab dan peduli akan lingkungannya(Ramdan \& Fauziah, 2019). Jadi dalam membangun karakter yang baik dalam diri anak didik adalah setiap guru, lembaga pendidikan atau sekolah harus menereapkan budaya sekolah dalam Budaya sekolah dalam pembentukan karakter ini harus secara terus-menerus dibangun dan dilakukan oleh seluruh stakeholder di sekolah yaitu kepa;a sekolah, guru, staf siswa, orang tua, masyrakat dan pemerintah. Peran guru memiliki peran penting dalam mengenalkan nilai karakter yang ditanaman kepada anak (Pitaloka et al., 2021). Peran guru sebagai teladan ditunjukkan oleh tutur kata, sikap, dan kepribadiannya, seperti sopan santun, disiplin, tanggung jawab, toleransi, jujur, serta kepedulian terhadap peserta didik dan orang lain(Palunga \& Marzuki, 2017). Penelitian sebelumnya menunjukkan adanya peran guru dalam perkembangan karakter siswa. Pada penelitian ini di fokuskan pada peran guru dalam menumbuhkan sikap peduli lingkungan. Peran guru dalam hal ini adalah guru sebagai pengelolah dan pengarah pembelajaran. Upaya-upaya dalam menanamkan karakter peduli lingkungan melalui program sekolah adiwiyata di SDN 114 Pekanbaru yang mendukung dan menghabat pembentukan karakter peduli lingkungan, dan mengidentifikasi dampak program sekolah adiwiyata. Sehingga tujuan penelitian ini yaitu menganalisis peran guru dalam membentuk karakter siswa peduli terhadap lingkungan pada sekolah adiwiyata di SD. Implikasi penelitian ini diharapkan dapat membantu guru dalam mengembangankan karakter peduli lingkungan terhadap sisiwa.

\section{METODE}

Metode yang digunakan dalam penelitian ini adalah deskriptif dengan pendekatan kualitatif, menurut Rahmat (2009:2) pendekatan kualitatif yaitu "penelitian yang tidak melakukan perhitungan, tetapi menggambarkan hasil penelitian yang diperoleh dari lapangan dengan menggunakan kata-kata atau kalimat (deskriptif). Untuk mendapatkan kesimpulan " Penelitian ini mendeskripsikan peran guru dalam membentuk karakter siswa terhadap peduli lingkungan melalui sekolah Adiwiyata. Subjek penelitian ini terdari dari kepala sekolah dan 2 guru kelas V. Penelitian ini dilakukan secara bertahap, peneliti merencanakan penelitian pada bulan Agustus 2021 dan September 2021. Teknik pengumpulan data dalam penelitian ini adalah wawancara, observasi, dan dokumentasi. Analisis data menggunakan model Milles \& Huberman yang berlangsung secara terus menerus dengan tahapan reduksi data, penyajian data dan penarikan kesimpulan (Sugiyono, 2019).

Penerapan program Adiwiyata terdiri dari sub indikator yaitu: misi, misi dan tujuan sekolah SDN 114 Pekanbaru, mengamati perencanaan program adiwiyata dalam pembelajaran, mengamati adannya keterlibatan komite sekolah dan masyarakat sekitar, dan mengamati ada tidaknya sarana yang mendukung program adiwiyata. Pada peran guru serta kendala dan solusi dalam program Adiwiyata sebagai penumbuh sikap peduli lingkungan, adapun sub indikatornya yaitu: megamati peran guru dalam pembelajaran, mengamati peran guru di luar pembelajaran, mengamati kendala pada program adiwiyata, mengamati adannya kendala penyerapan informasi pembelajaran adiwiyata oleh siswa, Mengamati kendala penerapan adiwiyata, mengamati solusi program pembelajaran dan penerapan program adiwiyata. Sedangkan pada program Adiwiyata menumbuhkan sikap peduli lingkungan pada peserta didik, yaitu: mengamati cara siswa berkomunikasi hasil inovasi pembelajaran, mengamati pelaksanaa kegiatan memungut sampah setiap hari, mengamati pemeliharan tanaman oleh masing-masing kelas, dan mengamati pemanfaatan prasarana lingkugan di sekolah. 


\section{HASIL DAN PEMBAHASAN}

Hasil

Pelaksanaan Program Adiwiyata Dalam Mendukung Pembentukan Karakter Peduli Lingkungan. Salah satu impelemtasi konsep green school dan green curricullum di Indonesia adalah program Adiwiyata. Program Adiwiyata merupakan bentuk komitmen pemerintahan terhdap pengelolahan dan perlindugan lingkungan melalui pendidikan. Kebijakan yang dibuat oleh pemerintah melalui Peraturan Mentri Lingkungan Hidup Nomor 5 Tahnun 2013 diterjemahkan menjadi program sekolah Adiwiyata. Program sekolah Adiwiyata memiliki empat aspek didalam pelaksanaan, antara lain adalah aspek kebijakan berwawasan lingkungan, aspek kurikulum sekollah berbasis lingkungan, aspek kegiatan berbasis partisiipatif dan yang terakhir adalah aspek pengelolahan sarana pendukung ramah lingkungan. Aspek-aspek tersebut berperan dalam mengkondisikan lingkungan sekolah untuk membiasakan perilaku peduli lingkungan siswa dan warga sekolah lainnya. Pembiasaan perilaku peduli lingkungan tersebut akan membentuk karakter peduli lingkungan siswa, dan siswa akan mempunyai kebiasaan untuk menjaga, merawat dan melestarikan lingkungannya. Berikut merupakan pelaksanaan program Adiwiyata di sekolah yang menjadi subjek penelitian

Program Adiwiyata yang dilaksanakan di SDN 114 Pekanbaru mengacu pada prinsip pelestarian fungsi lingkungan. Pengedalian pencernaan dan/ atau kerusakan lingkungan hidup. Internalisasi perlindungan dan pengolahan lingkungan hidup tersebut dikembangkan dalam bentuk program kegiatan tuntunan. Berikut adalah implementasi program Adiwiyata di SDN 114 Pekanbaru Pertama adalah kebijakan sekolah berwawasan lingkungan, yaitu visi, misi dan tujuan dan kurikulum sekolah mencantumkan perlindungan dan pengelolaan lingkungan hidup. Visi, misi dan tujuan sekolah yang tertuang dalam kurikulum sekolah sudah membuat kebijakan perlindungan dan pengelolahan lingkungan hidup. Visi, misi dan tujuan ini juga sudah terinternalisasi (tahu dan paham) oleh semua warga sekolah. Kebijakan di sekolah yang berbasis lingkungan dapat dilihat dari visi, misi dan tujan serta kurikulum yang diterapkan sekolah, selanjutnya tujuan sekolah yang berkaitan dengan lingkungan.

Kedua adalah pelaksanaan kurikulum berbasis lingkungan pelaksanaan di SDN 114 Pekanbaru diantarnya adalah pembelajaran Mulok Lingkungan Hidup seperti budi daya tanaman, pembeinihan ikan, pemanfaatan limbah untuk handy craf dan composting. Integrasi Pendidikan Lingkungan pada mata pelajaran yang relevan, yaitu dengan mengembangkan issu lokal dan issu global misalnya, pencemaran air, udara, tanah, kebakaran hutan, banjir, pengenalan energi alternatif dan terbarukan, pelestarian bdak bercula. Hal ini penting untuk membentuk karakter siswa peduli lingkungan. Proses pembelajaran tersebut jika terus menerus akan mendorong siswa untuk memahami isu lingkungan secara mendalam (Mukminin, 2014). Ketiga adalah kegiatan berbasis partisipatif. Kegiatan berbasis partisipatif yang dilakukan oleh warga sekolah di SDN 114 Pekanbaru diantarnya ialah kegiatan perawatan/ pemeliharaan sarana dan prasarana oleh warga sekolah misalnya dengan adannya piket kelas, kegiatan opsih, pemeliharaan sampah dan lainnya pemanfaatan lahan sekolah untuk pembelajaran Lingkungan Hidup misalnya, inventarisasi tanaman, pembibitan, budi daya tanaman, huitan sekolah, pengecekan kandungan zat pewarna dan bahan berbahaya pada jajanan kantin dan lain sebagainya mengembangkan kegitan esktarkulikuler berbasis lingkunga misalnya, melalui kegiatan pencita Alam, PMR/ UKS, pramuka, Olahraga, Prestasu, Majalah Dinding, Paskibraka, dan Seni Teater dan lainnya. Mengikuti aksi lingkungan dan peringatan hari-hari Lingkungan hidup melalui berbagai kegiatan misalnya: kampanye penggunaak moda transportaaasi ramah lingkungan, lomba melukis, lomba foto, lomba mading, lomba puisi dan karya tulis dan lain sebagainya. Cerminan sekolah adiwiyata juga ada pada setiap individu-individu di dalamnya, individu yang ada dalam sekolah adiwiyata sebagian besar memiliki jiwa cinta dan peduli lingkungan, hal itu dikarenakan organisasi yang dianut dalam hal ini sekolah telah memberlakukan budaya sekolah yang berwawasan lingkungan. Budaya sekolah merupakan sistem nilai sekolah dan akan mempengaruhi cara pekerjaan dilakukan serta cara warga sekolah berperilaku (Pahru et al., 2021; B. I Permana \& Ulfatin, 2018).

Keempat adalah pengelolahan sarana pendukung ramah lingkungan yang dilakukan oleh warga sekolah di SDN 114 Pekanbaru diantaranya penyedian sarana prasarana untuk mengatasi permasalahan lingkungan hidup di sekolah, misalnya tong sampah, TPS, sumur resapan, ruang kompois dan lain sebagainya. Penyediaan sarana dan prasarana untuk mendukung pembelajaran lingkungan hidup di sekolah, terpeliharannya sarana dan prasarana sekolah ramah lingkungan, misalnya: pemeliharaan taman, gedung, hutan sekolah, tanaman, gedung lain sebagainya. Penigkatan pengelelolahan dan pemeliharaan fasilitas sanitas sekolah, misalnya pemeliharaan drainase, pembersihan kamar mandi/ WC, pengelolahan sampah dan lain sebagainya. Pemanfaatan listrik, air dan alat tulus kantor secara efesien, misalnya penghematan listrik, kertas, dan alat-alat tulis lainnya. Peningkatan kualitas pelayanan kantin sehat dan 
ramah lingkungan, misalnya penyediaan kantin yang referensi, pengontrol jajanan siswa, pengetesaan kandung bahan pengawet dan zat berbahaya pada makanan, penyuluhan dan pembinaan petugas kantin dan lain sebagainya. Hal ini diperkuat dengan penelitian sebelumnya yang menyatakan mengembangkan program Adiwiyata sekolah sangat penting baik itu pada aspek kebijakan, kurikulum, kegiatan-kegiatan lingkungan, sarana dan prasarana yang mendukung maupun dalam segi pembiayaan program adiwiyata sekolah (Desfandi et al., 2017; Mukminin, 2014; B. I Permana \& Ulfatin, 2018). Oleh karena itu sarana dan prasarana yang baik dan lengkap sangat penting dalam menjalankan program adiwiyata.

Penggelolahan sarana dan prasarana atau fasilitas pendidikan harus selalu dijadikan oleh pihak sekolah dengan dukungan dari semua warga sekolah, orang tua peserta didik dan semua pemangku kebijakan. Sebagainya sekolah yanh telah merintis program pengelolaan dan pelestarian Lingkungan Hidup sejak tahun 2203, tentu saja SDN 114 Pekanbaru ingin terus membangun komitmen dan konsistensi penanaman nilai-nilai budaya ramah lingkungan serta pelestarian lingkungan hidup kepada semua warga sekolah dan warga masyrakat umumnya. Internalisasi budaya ramah lingkungan serta penting ditanamkan kepada para siswa di sekolah dan warga sekolah dengan harapan dimemukakan hari setelah mereka menjadi bagian dari warga masyrakat, mereka dapat mengimplemnetasi nilai-nilai kencintaan dan plestarian lingkungan hidup dalam kehidupan sehari-hari. Hal ini sangat penting mengingat kesadaran measyrakat terhadap pemeliharan dan plestarian lingkungan hidup masih rendah, sebagai buktinya yaitu kerusakan lingkungan baik itu pencernaran, kerusakan hutan, berkurangnnya berbagai species hewan kesuburan dan produktivitas tanah, dan lain-lain semakin bertambah dari tahun ketahun, sekolah sebagai lembaga yang akan mencetak generasi yang mampu mewariskan bumi kita kepada generasi mendatang agar dapat menopong kehidupannya. Budaya sekolah dibangun dari kepercayaan yang dipegang teguh secara mendalam tentang bagaimana sekolah seharusnya dikelola atau dioperasikan. budaya sekolah dapat diartikan sebagai perilaku, nilai-nilai dan cara hidup warga sekolah. Budaya ini perlu dikembangkan ke arah yang positif sebagai dasar dalam memahami dan memecahkan berbagai persoalan yang muncul di sekolah (Kusumaningrum et al., 2017; Rachmawati et al., 2018).

Program Adiwiyata menghendaki visi, misi dan tujuan serta kurikulum sekolah yang berbasis lingkungan. Keempat hal tersebut merupakan landasan sekolah dalam menjalankan kegiatan di sekolah. Setiap kebijakan yang diambil sekolah harus memperhatikan aspek lingkungan. Selain itu sekolah juga wajib memfasilitaskan pembelajaran ataupun sarana dan prasarana dalam menunjang pendidikan lingkungan seperti yang tercantum dalam visi,misi, tujuan dan kurikulum yang telah dirumuskan dan ditetapkan di sekolah. Visi, misi dan tujuan ini juga sudah terinternalisasi )tahu atau paham) oleh semua warga sekolah. Visi, misi dan tujuan sekolah sering di sosialisasikan kepada warga sekolah, tujuannya agar siswa lebih mengetahui dan memahami akan tujuan dari visi misi dan tujuan sekolah tersebut. Akan tetapi ketika saya melakukan wawancara dengan berbagai siswa di sekolah, mereka menyatakan bahwa hampir sebagai hapal visi, misi dan tujuan sekolah mereka kurang begitul hapal, dikarnakan poin dalam misi dan tujuan sekolah terlalu banyak/ dan agak sulit untuk di hapal. Untuk itu sosialisai yang berkaitan dengan visi, misi dan tujuan sekolah harus selalu dijadikan, agar kebijakan dan program yang akan dijadikan dan program yang akan dijalankan oleh sekolah berjalan dengan lancar dan sesuai dengan cita-cita yang diharpkan. Selanjutnya untuk mendukung pelaksanaan program Adiwiyata tersebut, pihak sekolah atau dalam ini pemangkuan kebijakan di sekolah (kepala sekolah, guru dan komite sekolah) mengalokasikan anggaran sekolah sebesar 20-30\% dari total anggaran keseluruhan Anggaran tersebut.

Pengembangan Kurikulum dan Pengelolahan Sarana dan Prasarana Berbasis Lingkungan. Sekolah dalam menentukan kebijakan melibatkan beberapa pihak. Kebijakan tentang program Adiwiyata teertuang dalam SK Kementrian Negara Lingkungan Hidup yang kemudian disosialisasikan ke sekolahsekolah dalam upaya mewujudkan sekolah agar peduli dan berbudaya lingkungan. Surat keputusan Nomor : Kep.07/MENLH/06/2005 dan Nomor : 05/VI/KB/2005 yang pada tahun 2010 diperuntukan bagi kepala Dinas Pendidikan Kabupaten dan Kota di seleuruh Indonesia, yang isinya secara garis besar mengenai himbauan agar pendidikan lingkungan hidup dilaksanakan di sekolah mulai tingakat SD hingga SMA dengan mengintegrasikan materi Lingkungan Hidup dalam kegiatan kurikuler dan ektra kurikuler untuk mewujudkan sekolah bebudaya lingkungan. Dari sosialisasi SK mentri tersebut sekolah membuat kebijkan yang tertuang di Surat Keputusan Kepala SDN 114 Pekanbaru. Kebijakan kepala sekolah yang diterapkan di sekolah tersebut sudah diberlakukan. Kebijakan yang dituangkan tersebut dijabarkan dalam bebrapa ketentuan kebijakan yang meliputi kebijkan sekolah peduli lingkungan dan berbudaya lingkungan, kebijakan pengembangan kurikulum berbasis lingkungan hidup yang di muat KTSP, kebijakan anggaran untuk mengalokasikan kegiatan terkait dan kebijakan tentang sarana dan prasarana yang memadai dalam mendukung pelaksanaan kurikulum pendidikan lingkungan hidup di sekolah. Disampaikan pula bahwa dalam pembentukan karkater kebijakan tersebut, melibatkan beberapa pihak, baik dari sekolah utamanya guru, wakil kepala sekolah, bagian kurikulum, dan komite sekolah (Desfandi et al., 2017). Sekolah adiwiyata ada pada setiap individu-individu di dalamnya, individu yang ada dalam 
sekolah adiwiyata sebagian besar memiliki jiwa cinta dan peduli lingkungan, hal itu dikarenakan organisasi yang dianut dalam hal ini sekolah telah memberlakukan budaya sekolah yang berwawasan lingkungan (Aini et al., 2021; Asyifa et al., 2019; B. I Permana \& Ulfatin, 2018). Sehingga seluruh komponen sekolah harus terlibat dalam kegiatan sekolah adiwiyata.

Dukungan sekolah dalam rangka menwujudkan pelestarian lingkungan, keterlibatan semua komponen masyrakat mutlak diperlukan. Untuk mewujudkan sekolah yang peduli dan berbudaya lingkungan. Warga sekolah perlu dilibatkan dalam berbagai aktifitas pembelajaran lingkungan hidup selain itu sekolah juga diharapkanmelibatkan masyrakatsekitarnya dalam melakukan berbagai kegiatan yang memberikan manfaat baik warga sekolah msyarakat maupun lingkungan. Pelaksanaan Kurikulum Berbasis Lingkungan meliputi pertama perencanaan pembelajaran, setiap guru SDN 114 Pekanabru telah membuat rencana pelaksanaan pembelajaran (RPP) berbasis linkungan. RPP disusun sesuai dengan KD dan indikator dan materi pembelajaran yang sesuaikan dengan pembelajaran berbasis linkungan. Tujan pembelajaraan pembelajaran yang berkaitan dengan peduli lingkungan diintegrasikan dalam RPP. RPP yang terdapat muatan tentang lingkungan diberi warna hijau sehingga guru mengetahui jika terdapat muatan tentang linkungan diberi warna hijau sehingga guru mengetahui jika terdapat muatan pendidikan karakter peduli lingkungan. Kedua, pelaksanaan pembelajaran. Pelaksanaan pembelajaran berbasis lingkungan di SDN 114 Pekanbaru telah diintegrasikan ke dalam semua muatan pembelajaran yang ada kaitannya dengan materi lingkungan. Metode yang digunakan guru dalam pelaksanaan pembelajaran peduli lingkungan yaitu ceramh, tanya jawab, diskusi, wawancara, observasi, penugasan. Permainan dan praktik langsung. Media pembelajaran yang digunakan untuk menyampaikan materi yang berkaitan dengan pelaksanaan pendidikan peduli lingkungan yaitu komposter, kulit telur, botol plastik dan tumbuh yang terdapat di lingkungan sekolah. Dengan persiapan dalam melaksanakan pembelajaan baik, maka kegitan pembelajaran akan menjadi lebih baik (Iswantiningtyas \& Wulansari, 2018; Natajaya \& Yudana, 2014).

Impelemtasi kebijakan kurikulum berbasis lingkungan hidup pada program Adiwiyata Mandiri di SDN 114 Pekanbaru sering kali berbagai problematika yang tidak ringan. Oleh karena itu sekolah harus dapat merespon dengan mengatasi masalah-masalah yang mungkin dapat menghambatan jalannya kebijakan yang diterapkan. Adalah beberapa faktor yang dapat menghambat implementasi kebijakan implementasi kurikulum berbasis lingkungan hidup di sekolah tersebut, antara lain pertam guru, salah satu hambatan yang terlihat dari hasil wawancara penelitian dengan salah seorang guru di SDN 114 Pekanabru adalah guru dalam mengejar terlihat kurang variasi dalam mengembangkan materi pembelajaran lingkungan hidup. Sehingga penyampaiannya kepada siswa kurang dapat dipahami, dan guru kurang mampu memberikan penyampaian materinya dengan hal-hal baru yang dapat dihubungkan dengan keadaan lingkungan sekitar sekolah. Kedua, anak didik. Anak didik merupakan subjek pendidikan yang menjadi generasi penerus bangsa. Adannya perbedaan pola pendidikan yang dibawa anak diri lingkungan keluarga serta heterogenitas karakter dari setiap individu anak merupakan pengambat upaya peningkatan perkembangan sosial peserta didik. Terlihat tiap pergantian tahun ajaran baru siswa yang masuk di sekolah ini akan mendapatakan materi pelajaran lingkungan hidup. Ketiga sarana dan prasarana, banyak tersedia fasilitas yang memadai terdapat di sekolah ini sebagai bahan ajar penunjang materi lingkungan hidup. Kurangnya perhatian dan perawatan yang intens menjadikan beberapa fasilitas yang ada lambat rusak. Beberapa tempat sampah pemberian kontribusi pemerintah yang awalnya bagus terlihat tidak terawat ditempatkan disuatu sudut bangunan sekolah. Sehingga diperlukan pengadaan kembali, serta yang lebih diperhatikan adalah upaya untuk meningkatkan kesadaran menjaga fasilitas memadai di sekolah itu perlu ditegaskan lagi.

Untuk memperkecil hambatan yang terjadi, sekolah memberikan solusi strategis untuk mengatasi persoalan yang terdapat di sekolah. Dalam petikan wawaancara salah satu seorang guru menjelaskan bahwa strategi untuk mengatasi hambatan yang ada adalah dengan cara pertama pembinaan PLH. Hal ini merupakan kegiatan rutin yang dilakukan sekolah setiap semester, kebijakan kurikulum lingkungan hidup di sekolah ini selalu diperhatikan untuk di upayakan peremajaan agar sesuai dengan isu-isu lingkungan yang terjadi di sekitar. Sehingga guru dalam menguasai materi pembelajaran lingkungan hidup dapat siap setiap saat dalam memberikan materi ke siswanya. Kedua, menanamkan pembiasaan peduli lingkungan hidup, secara rutim guru memberikan ingatan kepada siswa akan pentingnya peduli kepada lingkungan sekitar dan maupun untuk menjaga kelestarian serta kebersihan. Ketiga mengoptimalkan fasilitas penunjang pembelajaran LH. Mengoptimalkan sarana penunjang untuk membuat susana belajar di sekolah tersebut terasa hidup. Nuansa yang seha, bersi, asri dan berhias warna hijau di masing-masing bangunan dan ornamen menambahkan kesan hidup kondusif. Keempat, berpartisipasi aktif dengan kegiatan aksi lingkungan, sekolah mengadakan agenda sekali dalam setahun untuk berbaur dengan diluar dengan mengajak masyrakat sekitaar peduli lingkungan dengan cara kampanye tentang kepedulian lingkungan dan menjaga keasrian lingkungan. Hal ini dapat dilakukan saat bertatapan dengan momen hari 
bumi yang biasanya diperingati di bulan oktober. Kelima, menciptakan kader siswa duta lingkungan hidup. Sekolah mempersiapkan kader siswa dalam setahun membuahkan duta-duta lingkungan yang dijadikan kebanggan dan dapat dijadikan sebagai teladan siswa lainnya untuk selalu dapat membiasakan perilaku peduli berbudaya terhadap lingkungan. Hal tersebut, pendidikan adalah menuntun segala kekuatan kodrat yang ada dalam diri peserta didik, supaya meraka dapat menjadi manusia \& menjadi bagian dari masyarakat yang baik sehingga mereka dapat mencapai kebahagiaan yang setinggi-tingginya (Pahru et al., 2021; Wiranata, 2020).

Keenam, pengelolahan sampah secara maksimal dan komposting. Sekolah sangat perhatian sekali dengan masalah sampah. Pemilihan sampah benr-benar dipilih secara cermat. Membagai sampah menjadi 2 kriteria yaitu sampah organik dan sampah anorganik. Ketujuh, mendirikan forum kelas peduli lingkungan sekolah. Komite lingkungan sekolah mempunyai peranan sebagai penjamin semua warga sekolah (termasuk murid) merasa terwakili untuk membuat keputusan dalam proses implementasi program (Desfandi et al., 2017; Mukminin, 2014). Untuk mendorong semua warga sekolah peduli terhadap eksistensi program, Menjamin bahwa program didukung oleh manajemen sekolah, dan sebagai media untuk berhubung atau melibatkan komunitas di luar sekolah dalam menajlan program. Kedelapan, membuat misi lingkungan. Misi lingkungan sekolah adalah suatu pernyataan yang jelas tentang harapan atau komitmen sekolah untuk meningkatkan kualitas lingkungan sekolah dan terciptannyabudaya terhadap lingkungan (Mardliyah et al., 2020; Tompodung et al., 2018). Dalam pembuatan misi lingkungan sekolah peran serta siswa sangat penting karena dengan melibatkan siswa dalam pembuatan misi lingkunganakan meningkatkan motivasi da rasa bertanggung jawab untuk mewujudkan apa yang terdapat dalam misi lingkungan sekolah.

\section{SIMPULAN}

Pelaksanaan progam Adiwiyata dalam pembelajaran di SDN 114 Pekanbaru dalam membentuk karakter sudah di terapkan guru dalam kegiatan pembelajaran Peran guru sebagai pendidik merupakan peran-peran yang berkaitan dengan tugas-tugas memberi bantuan dan dorongan (supporter), tugas-tugas pengawasan dan pembinaan (supervisor) serta tugas-tugas yang berkaitan dengan mendisplikan anak agar itu menjadi patuh terhadap aturan-aturan sekolah dan norma hidup dalam keluarga dan masyrakat. Kegiatan sekolah berbasis partisipatif memiliki standar dalam pelaksanaan kegiatan perlindungan dan pengelolaan lingkungan hidup yang terencana bagi warga sekolah serta menjalin kemitraan dalam rangka perlindungan dan pengelolaan lingkungan hidup dengan berbagai pihak (masyarakat, pemerintah, media, serta sekolah lain). Kendala dalam penerapan nilai karakter peduli lingkungan melalui implementasi etnoelogi dalam program Adiwiyata di SDN 114 Pekanbaru antara lainnya adalah kurangnnya maksimal peran guru dalam mengkondinir kegiatan Adiwiyata, dn juga waktu yang terbatas bagi peserta didik dalam menjalankan program adiwiyata. faktor pendukung dan penghambat pelaksanaan program Adiwiyata yang di laksanakan di SDN 114 Pekanbaru. Implemnetasi tersebut dilakukan dengan berpedoman pada masing-masing komponen Adiwiyata yaitu; kebijakan sekolah berwawasan lingkungan, kegiatan lingkungan, kurikulum berbasis lingkungan, kegiatan lingkungan berbasis partisipatif dan pengelolahan sarana dan prasarana rama lingkungan.

\section{DAFTAR PUSTAKA}

Aini, T. N., Akbar, S., \& Winahyu, S. E. (2021). Implementasi Program Adiwiyata Berbasis Partisipatif Dalam Menumbuhkan Nilai-Nilai Karakter di Sekolah Dasar. Sekolah Dasar: Kajian Teori Dan Praktik Pendidikan, 30(1), 57 - 70. https://doi.org/10.17977/um009v39i12021p057.

Asyifa, B. F., Rudyatmi, E., \& Abdullah, M. (2019). The Development of Plant Encyclopedia Based on Datebase in Adiwiyata Senior High School. Unnes Journal Of Biology Education, 8(1), 1 - 7. https://doi.org/10.15294/jbe.v8i1.26526.

Citra Ningrum, C. H., Fajriyah, K., \& Budiman, M. A. (2019). Pembentukan Karakter Rasa Ingin Tahu Melalui Kegiatan Literasi. Indonesian Values and Character Education Journal, 2(2), 69. https://doi.org/10.23887/ivcej.v2i2.19436.

Desfandi, M., Maryani, E., \& Disman, D. (2017). Building Ecoliteracy Through Adiwiyata Program (Study at Adiwiyata School in Banda Aceh). Indonesian Journal of Geography, 49(1), 51 - 56. https://doi.org/10.22146/ijg.11230.

Gazali, N., Cendra, R., Candra, O., Apriani, L., \& Idawati, I. (2019). Penanaman Nilai-Nilai Karakter Peserta Didik Melalui Ekstrakurikuler Pramuka. Aksiologiya: Jurnal Pengabdian Kepada Masyarakat, 3(2), 201. https://doi.org/10.30651/aks.v3i2.1898.

Irwansa, A., \& Maf'ul, M. A. (2018). Analisis pelaksanaan tata tertib sekolah pada siswa di smk negeri 1 
$\begin{array}{lllll}\text { makassar. Open } & \text { Journal }\end{array}$

https://ojs.unm.ac.id/tomalebbi/article/download/1670/716.

Iswantiningtyas, V., \& Wulansari, W. (2018). Pengembangan Model Penilaian Pendidikan Karakter Anak Usia Dini. JPUD - Jurnal Pendidikan Usia Dini, 12(2), 361-370. https://doi.org/10.21009/jpud.122.17.

Kusumaningrum, D. E., Sumarsono, R. D., \& Gunawan, I. (2017). Problematika Pemberdayaan dan Pengembangan Sumber Daya Manusia di Sekolah Menengah Pertama Berbasis Pesantren. Ilmu Pendidikan: Jurnal Kajian Teori Dan Praktik Kependidikan, 2(2), 139-150. https://doi.org/10.17977/um027v2i22017p139.

Madja, I. K. (2019). Pemoralitasan Sebagai Pola Dasar Pengembangan. 6, 54-63. http://dx.doi.org/10.25078/gw.v6i1.865.

Mardliyah, S., Yulianingsih, W., \& Putri, L. S. R. (2020). Sekolah Keluarga: Menciptakan Lingkungan Sosial untuk Membangun Empati dan Kreativitas Anak Usia Dini. Jurnal Obsesi : Jurnal Pendidikan Anak Usia Dini, 5(1), 576. https://doi.org/10.31004/obsesi.v5i1.665.

Mukminin, A. (2014). Strategi Pembentukan Karakter Peduli Lingkungan di Sekolah Adiwiyata Mandiri. Ta'dib: Jurnal Pendidikan Islam, 19(2), 227-252. https://doi.org/10.19109/td.v19i02.16.

Natajaya, I. N., \& Yudana, I. M. (2014). Pelaksanaan Pendidikan Karakter Melalui Pembelajaran Sejarah (Studi Kasus Pada Peserta Didik Di Sma Negeri 1 Marga Tabanan). Jurnal Administrasi Pendidikan, $5(1)$.

Nurwaqidah, S., Suciati, S., \& Ramli, M. (2020). Environmental literacy-based on adiwiyata predicate at junior high school in Ponorogo. Jurnal Pendidikan Biologi Indonesia, 6(3), 405 - 412. https://doi.org/10.22219/jpbi.v6i3.12468.

Oktradiksa, A.-, \& Sari, K. P. (2017). Implementasi Multi-Directional Circle Model dalam Mewujudkan Madrasah Ibtidaiyah Adiwiyata di Kabupaten Magelang. AL IBTIDA: Jurnal Pendidikan Guru Mi, 4(2), 153 - 164. https://doi.org/10.24235/al.ibtida.snj.v4i2.1727.

Pahru, S., Akbar, S., \& Hitipeuw, I. (2021). Pelaksanaan Program Adiwiyata dalam Mendukung Pembentukan Karakter Peduli Lingkungan. Jurnal Pendidikan: Teori, Penelitian Dan Pengembangan, 6(1). https://doi.org/10.17977/jptpp.v6i1.14405.

Palunga, R., \& Marzuki. (2017). Peran Guru Dalam Pengembangan Karakter Peserta Didik Di Sekolah Menengah Pertama Negeri 2 Depok Sleman. Jurnal Pendidikan Karakter, 7(1). https://doi.org/10.21831/jpk.v7i1.20858.

Permana, B. I, \& Ulfatin, N. (2018). Budaya sekolah berwawasan lingkungan pada sekolah adiwiyata mandiri. , 3(1).. Ilmu Pendidikan: Jurnal Kajian Teori Dan Praktik Kependidikan, 3(1), 11-21. https://doi.org/10.17977/um027v3i12018p011.

Permana, Bayu Indra, \& Ulfatin, N. (2018). Budaya Sekolah Berwawasan Lingkungan pada Sekolah Adiwiyata Mandiri. Jurnal Kajian Teori Dan Praktik Pembelajaran, 2(1). https://doi.org/10.17977/um027v3i12018p011.

Pitaloka, D. L., Dimyati, D., \& Edi, P. (2021). Peran Guru dalam Menanamkan Nilai Toleransi pada Anak Usia Dini di Indonesia. Jurnal Obsesi : Jurnal Pendidikan Anak Usia Dini, 5(2), 1696-1705. https://doi.org/10.31004/obsesi.v5i2.972.

Prasanti, D., \& Fitrianti, D. R. (2018). Pembentukan Karakter Anak Usia Dini: Keluarga, Sekolah, Dan Komunitas. Pembentukan Anak Usia Dini : Keluarga, Sekolah, Dan Komunitas, 2(1), 15.

Purwanti, D. (2017). Pendidikan Karakter Peduli Lingkungan Dan Implementasinya. Dwija Cendekia: Jurnal Riset Pedagogik, 1(2), 14-20. https://doi.org/10.20961/jdc.v1i2.17622.

Putry, R. (2019). Nilai Pendidikan Karakter Anak Di Sekolah Perspektif Kemendiknas. Gender Equality: International Journal of Child and Gender Studies. https://doi.org/10.22373/equality.v4i1.4480.

Rachmawati, W., Benty, D. D. N., \& Sumarsono, R. B. (2018). Budaya Sekolah Berbasis Ketarunaan Dalam Pembentukan Karakter Peserta Didik. Jurnal Administrasi Dan Manajemen Pendidikan, 1, 410-418. https://doi.org/10.17977/um027v1i42018p410.

Rahmawati, M., \& Harmanto. (2020). Pembentukan Nilai Karakter Toleransi dalam Pembelajaran Pendidikan Pancasila dan Kewarganegaraan Bagi Siswa Tunagrahita. Journal of Civics and Moral Studies, 5(1), 59-72.

Ramdan, A. Y., \& Fauziah, P. Y. (2019). Peran orang tua dan guru dalam mengembangkan nilai-nilai karakter anak usia sekolah dasar. Jurnal Pendidikan Dasar Dan Pembelajaran, 9(2), 100. https://doi.org/10.25273/pe.v9i2.4501.

Rohmah, U. (2018). Pendidikan Karakter pada Anak Usia Dini. Societas Dei: Jurnal Agama Dan Masyarakat, 5(2), 180. https://doi.org/10.33550/sd.v5i2.89.

Salsabilah, azka salmaa, Dewi, dinie anggraeni, \& Furnamasari, yayang furi. (2021). Peran Guru Dalam $\begin{array}{llll}\text { Pendidikan } \quad \text { Karakter } & \text { 7164-7169. }\end{array}$ 
https://jptam.org/index.php/jptam/article/view/2106.

Sholikhah, T. I. (2017). Pendidikan karakter peduli lingkungan (studi kasus di sekolah menengah Assalihiyah, Thailand). Attarbiyah, 27, 19. https://doi.org/10.18326/tarbiyah.v27i0.19-42.

Sunarsi, D., \& Asmalah, L. (2018). Pelatihan Manajemen Pengembangan Diri Bagi Penerima Beasiswa Rzis Ugm Dan Dompet Shalahuddin Jogjakarta. Jurnal Pengabdian Dharma Laksana, 1(1), 51-60. http://rumahzis.ugm.ac.id/.

Syahriani, S., Dalifa, \& Resnani. (2018). JuRiDikDas. 1(2), 105-114. https://ejournal.unib.ac.id/index.php/juridikdasunib/article/download/5823/2810.

Tompodung, T. C. G., Rushayati, S. B., \& Aidi, M. N. (2018). Efektivitas Program Adiwiyata Terhadap Perilaku Ramah Lingkungan Warga Sekolah Di Kota Depok. Journal of Natural Resources and Environmental Management, 8(2). https://doi.org/10.29244/jpsl.8.2.170-177.

Tresnani, lia dwi. (2020). Penanaman Karakter Peduli Lingkungan melalui Kegiatan Pembiasaan di SMP Negeri 6 Pekalongan. AL-HIKMAH Uurnal Pendidikan Dan Pendidikan ..., 2(1), 108-117. http://www.ejournal.uniks.ac.id/index.php/Alhikmah/article/view/431.

Wardani, Septiana, M., Nugroho, N. R. I., \& Ulinnuha, M. taufiq. (2019). Penguatan Pendidikan Karakter dalam Proses Pembelajaran Bahasa Inggris. Buletin Literasi Budaya Sekolah, 1(1), 27-33.

Wiranata, I. G. L. A. (2020). Penerapan Positive Parenting Dalam Pembiasaan Pola Hidup Bersih dan Sehat Kepada Anak Usia Dini. Jurnal Pendidikan Anak Usia Dini, 5(1), 82-88. https://doi.org/10.25078/pw.v5i1.1362. 